\title{
Paracrine regulation of somatostatin secretion by insulin and glucagon in mouse pancreatic islets
}

\author{
Berit Svendsen $^{1,2}$ (D) Jens J. Holst ${ }^{1,2}$ (D \\ Received: 7 May 2020 / Accepted: 26 July 2020 / Published online: 12 October 2020 \\ (C) Springer-Verlag GmbH Germany, part of Springer Nature 2020
}

\begin{abstract}
Aims/hypothesis The endocrine pancreas comprises the islets of Langerhans, primarily consisting of beta cells, alpha cells and delta cells responsible for secretion of insulin, glucagon and somatostatin, respectively. A certain level of intra-islet communication is thought to exist, where the individual hormones may reach the other islet cells and regulate their secretion. Glucagon has been demonstrated to importantly regulate insulin secretion, while somatostatin powerfully inhibits both insulin and glucagon secretion. In this study we investigated how secretion of somatostatin is regulated by paracrine signalling from glucagon and insulin.

Methods Somatostatin secretion was measured from perfused mouse pancreases isolated from wild-type as well as diphtheria toxin-induced alpha cell knockdown, and global glucagon receptor knockout $\left(\mathrm{Gcgr}^{--}\right)$mice. We studied the effects of varying glucose concentrations together with infusions of arginine, glucagon, insulin and somatostatin, as well as infusions of antagonists of insulin, somatostatin and glucagon-like peptide 1 (GLP-1) receptors.

Results A tonic inhibitory role of somatostatin was demonstrated with infusion of somatostatin receptor antagonists, which significantly increased glucagon secretion at low and high glucose, whereas insulin secretion was only increased at high glucose levels. Infusion of glucagon dose-dependently increased somatostatin secretion approximately twofold in control mice. Exogenous glucagon had no effect on somatostatin secretion in $\mathrm{Gcgr}^{-/}$mice, and a reduced effect when combined with the GLP-1 receptor antagonist exendin 9-39. Diphtheria toxin-induced knockdown of glucagon producing cells led to reduced somatostatin secretion in response to $12 \mathrm{mmol} / \mathrm{l}$ glucose and arginine infusions. In $\mathrm{Gcgr}^{-/}$mice (where glucagon levels are dramatically increased) overall somatostatin secretion was increased. However, infusion of exendin 9-39 in $\mathrm{Gcgr}^{-/-}$mice completely abolished somatostatin secretion in response to glucose and arginine. Neither insulin nor an insulin receptor antagonist (S961) had any effect on somatostatin secretion.

Conclusions/interpretation Our findings demonstrate that somatostatin and glucagon secretion are linked in a reciprocal feedback cycle with somatostatin inhibiting glucagon secretion at low and high glucose levels, and glucagon stimulating somatostatin secretion via the glucagon and GLP-1 receptors.
\end{abstract}

Keywords Glucagon · Intra-islet communication · Perfused mouse pancreas · Somatostatin secretion

Abbreviations

DT Diphtheria toxin

DT-Geg Diphtheria toxin-induced glucagon knockdown

Berit Svendsen

bsvendsen@sund.ku.dk

$\triangle$ Jens J. Holst

jjholst@sund.ku.dk

1 NovoNordisk Foundation Center for Basic Metabolic Research, Faculty of Health and Medical Sciences, University of Copenhagen, Copenhagen, Denmark

2 Department of Biomedical Sciences, Faculty of Health and Medical Sciences, University of Copenhagen, Copenhagen, Denmark
Ex9 Exendin 9-39

GLP-1 Glucagon-like peptide-1

\section{Introduction}

The endocrine pancreas comprises the islets of Langerhans, which are scattered in the exocrine pancreas. The islets are micro organs consisting of about a couple of hundred to a couple of thousand endocrine cells, including the beta cells, alpha cells, delta cells, pancreatic polypeptide cells and epsilon cells. These cells are responsible for the secretion of insulin, glucagon, somatostatin, pancreatic polypeptide and ghrelin, respectively. 


\section{Research in context}

\section{What is already known about this subject?}

- Somatostatin strongly inhibits insulin and glucagon secretion

- Exogenous glucagon can stimulate secretion of insulin and somatostatin from pancreatic islets

- Glucagon receptors and GLP-1 receptors are expressed on somatostatin-producing delta cells

What is the key question?

- Is somatostatin secretion regulated by endogenous paracrine glucagon and insulin signalling?

What are the new findings?

- Blocking intra-islet glucagon signalling reduces pancreatic somatostatin secretion

- Insulin does not directly affect secretion of somatostatin in mouse islets

How might this impact on clinical practice in the foreseeable future?

- The findings indicate that glucagon is necessary to maintain normal somatostatin secretion. Considering the strong inhibitory role somatostatin plays on insulin and glucagon secretion, control of somatostatin secretion could contribute to better regulation of insulin and/or glucagon

The somatostatin-producing delta cells comprise $\sim 5 \%$ of the islet cells [1]. A certain level of intra-islet communication is thought to exist, where the individual hormones may reach and regulate the secretion of other islet cells, either via diffusion through the interstitial fluid or via transportation by the islet microcirculation. Based on the 'intra-islet hypothesis', the anatomical correlate of which is that blood within the islets flows from beta cells to alpha cells to delta cells, the local actions of somatostatin would be expected to be negligible [2, 3], while secreted somatostatin would be expected to be exported for extra-islet actions. This view is, however, difficult to reconcile with the extremely rapid degradation of somatostatin in circulation, which makes even a several-fold increase in the local secretion undetectable in the peripheral circulation $[4,5]$. Attempts to reveal the intra-islet paracrine actions with immunoneutralisation have given conflicting results with both positive effects by retrograde perfusion of the pancreas [6], and no effect on insulin or glucagon secretion [7]. However, the well-established expression of somatostatin receptors on both alpha- and beta cells renders both cell types sensitive to the inhibitory influence of somatostatin [8-10]. Furthermore, in the perfused rat and mouse pancreas, infusion of somatostatin receptor antagonists resulted in increased glucagon secretion $[11,12]$, suggesting that somatostatin tonically inhibits glucagon secretion. Studies in mice with a genetic disruption of the gene encoding somatostatin supported the idea that both glucagon and insulin secretion are under tonic inhibitory control by somatostatin [13]. Thus, a role for somatostatin in the regulation of at least glucagon secretion seems established, but the converse: a paracrine regulation of somatostatin secretion by the other islet cells, has not been investigated in depth. Exogenous glucagon has been demonstrated to stimulate insulin secretion through glucagon and glucagon-like peptide 1 (GLP-1) receptors [14-17]. Somatostatin secretion may also be stimulated by glucagon [16, 17], but only few studies have investigated somatostatin secretion. There is little agreement regarding the possible effects of insulin, with either no or an inhibitory effect on glucagon secretion [18], and variable effects on somatostatin secretion in some studies [18, 19], and no effect of insulin on somatostatin secretion in other studies [20].

Here we investigated the secretion of somatostatin and how it is affected by glucagon and insulin, using the perfused mouse pancreas as an experimental model. Because of clear effects of exogenous glucagon on somatostatin secretion, we selected a range of complementary genetic and pharmacological approaches to disrupt local glucagon signalling. Thus, to eliminate glucagon secretion from the alpha cells, a transgenic mouse strain with diphtheria toxin (DT)-induced destruction of proglucagon-producing alpha cells was used [21]. For estimation of the importance of glucagon receptors, we used mice with global knockout of $\mathrm{Gcgr}\left(\mathrm{Gcgr}^{--}\right)$[22], and regarding the GLP-1 receptor we used the GLP-1 receptor antagonist exendin 9-39 (Ex9).

\section{Methods}

\section{Mice}

All experiments were conducted in compliance with our animal experiment license (2008/561-1491) issued by the Danish Committee for Animal Research, and approved by the local animal welfare committee at the University of Copenhagen. Studies were conducted in male mice 8-16 weeks of age, housed up to eight per cage and kept on a $12 \mathrm{~h}$ light-dark cycle 
with free access to standard chow and water. Randomisation was not considered relevant in these studies.

Perfusion experiments were performed with pancreases from both wild-type C57BL6/J mice (Taconic, Denmark), or mice with DT-induced knockdown of proglucagon-producing cells (DT-Gcg) which received i.p. injections of $10 \mathrm{ng} \mathrm{DT} / \mathrm{g}$ body weight on days 1, 3 and 5 followed by perfusion 10 days after the last injection [14], or global glucagon receptor knockout $\left(\mathrm{Gcgr}^{-/}\right)$mice as previously described [14, 21, 22]. The latter two studies included littermate control mice.

\section{Perfused mouse pancreas}

Pancreas perfusions were performed as previously described [14]. Briefly described, mice were anaesthetised with i.p. injection of ketamine $(90 \mathrm{mg} / \mathrm{kg}$; Ketaminol Vet.; MSD Animal Health, USA) and xylazine (10 mg/kg; Rompun Vet; Bayer Animal Health, Germany). The intestine, spleen, stomach and kidneys were tied off. The aorta was ligated proximally to the coeliac artery, and a catheter was inserted into the abdominal aorta allowing arterial perfusion with a modified Krebs-Ringer bicarbonate buffer $(0.1 \%$ BSA, $5 \%$ (wt/vol.) dextran in addition). Venous effluent was collected via a catheter in the portal vein. The perfusion system (UP-100 universal perfusion system, Hugo Sachs Elektronik, Germany) maintained constant flow of $1 \mathrm{ml} / \mathrm{min}$, perfusion buffer was heated and oxygenated $\left(95 \% \mathrm{O}_{2}, 5 \% \mathrm{CO}_{2}\right)$ and pressure was monitored throughout the experiment $(40-50 \mathrm{mmHg})$. Experiments exhibiting significant changes in pressure or flow $(>20 \%)$ were terminated and discarded.

\section{Experimental protocols}

After surgery and after perfusion with medium was initiated, the pancreas was allowed to stabilise for $30 \mathrm{~min}$ with the same perfusion medium and glucose concentration as that used immediately thereafter.

Protocol A In one series of experiments $(n=5-13)$, glucagon (0.1, 1 or $10 \mathrm{nmol} / \mathrm{l}$; Sigma-Aldrich, USA), insulin (0.1$1 \mu \mathrm{mol} / \mathrm{l}$; Actrapid, Novo Nordisk, Denmark), GLP-19-36 (10 nmol/l; Bachem, Switzerland), amino acid mix (arginine, glutamine, glutamate and alanine; $10 \mathrm{mmol} / \mathrm{l}$ of each), or somatostatin-14 (0.1 nmol/1; Bachem, Switzerland) were infused for $10-20 \mathrm{~min}$ at 3.5 or $12 \mathrm{mmol} / \mathrm{l}$ glucose separated by $20 \mathrm{~min}$ rest periods to allow secretion to return to basal level. Insulin receptor antagonist S961 (1 $\mu \mathrm{mol} / \mathrm{l}$; kind gift from Lauge Schäffer, Novo Nordisk, Denmark [23]), GLP-1 receptor antagonist Ex9 (1 $\mu \mathrm{mol} / \mathrm{l}$; Bachem, Switzerland), or somatostatin receptor antagonists PRL2915 + PRL3195 (H-6056 and H-5884; Bachem, Switzerland); $1 \mu \mathrm{mol} / 1$ of each) were infused at 3.5 or $12 \mathrm{mmol} / 1$ glucose.
Protocol B In a second set of experiments $(n=7-11)$, the pancreases were perfused at low glucose $(3.5 \mathrm{mmol} / \mathrm{l})$ followed by a switch to high glucose concentration $(12 \mathrm{mmol} / \mathrm{l})$ in the perfusion buffer.

In all experiments, L-arginine $(10 \mathrm{mmol} / \mathrm{l})$ was infused as positive control stimulus for $5 \mathrm{~min}$ periods during both glucose concentrations. In this series of experiments, inadequate control responses were not observed and did not lead to discard of any experiments. Experiments were carried out in wild-type mice \pm GLP-1 receptor antagonist Ex9 (1 $\mu \mathrm{mol} / \mathrm{l}$; Bachem, Switzerland), DT-Gcg mice and $\mathrm{Gcgr}^{-/}$mice, and each group was compared with their appropriate littermate control group [14].

\section{Hormone analyses}

Hormone concentrations in the perfusion effluent were measured using in-house radioimmunoassays. Somatostatin concentrations were determined using a rabbit antiserum (1758) raised against synthetic cyclic somatostatin, recognising both somatostatin 14 and 28, also in linear forms [12], somatostatin 14 as standard and ${ }^{125}$ I-labelled $\mathrm{Tyr}^{11}$ somatostatin (Perkin-Elmer, USA) as tracer. Glucagon was measured using a $\mathrm{COOH}$-terminally directed antiserum (4305), which measures fully processed glucagon as well as N-terminally extended molecular forms [24]. Insulin was measured using an antibody (2006-3) crossreacting strongly with rodent insulin I and II [25]. Rat insulin was used as standard. Sensitivities were below $1 \mathrm{pmol} / \mathrm{l}$ and intra-assay coefficients of precision $<6 \%$. The technician/investigator carrying out the hormone measurements was blinded to the origin of the samples.

\section{Statistical analyses}

All statistical analyses were conducted using GraphPad Prism 7.0 (GraphPad Software, USA). Responses to arginine and hormone infusions were evaluated by comparing mean hormone secretion for 5 or $10 \mathrm{~min}$ periods prior to infusion with hormone output during the infusion period using oneway ANOVA analysis with Tukey post hoc test. Data are expressed as mean $\pm \mathrm{SEM}$.

\section{Results}

\section{Glucagon and insulin secretion is inhibited by exogenous and endogenous somatostatin}

Initially, we confirmed that $0.1 \mathrm{nmol} / 1$ somatostatin infusion powerfully inhibits secretion of glucagon (Fig. $1 \mathrm{a} ; p<0.05$ ) and insulin (Fig. 1b; $p<0.01$ ) in the perfused mouse pancreases. This inhibitory effect on insulin and glucagon was further 

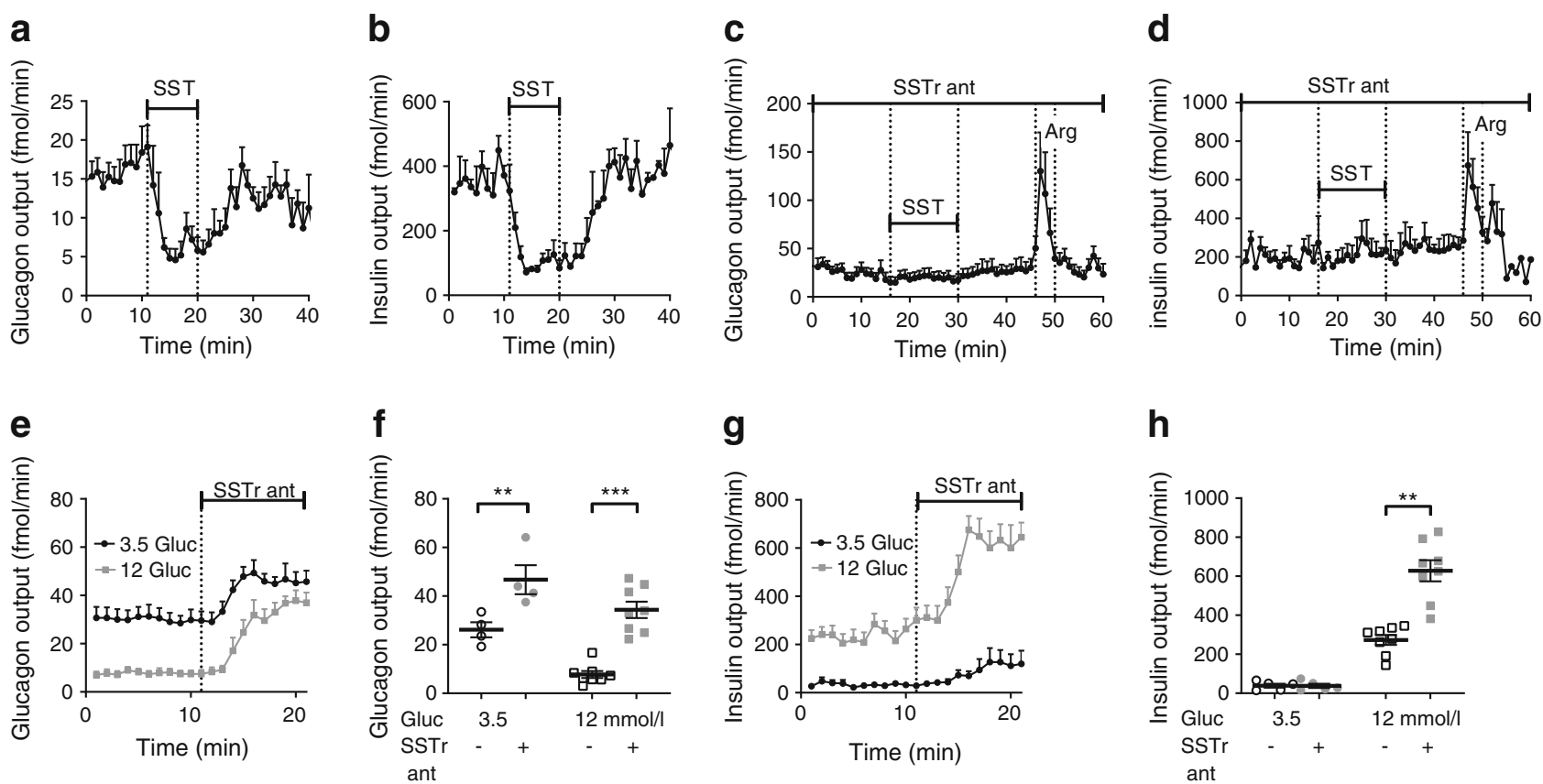

Fig. 1 Insulin and glucagon secretion is regulated by somatostatin. Insulin and glucagon secretion from perfused mouse pancreases during infusion of $0.1 \mathrm{nmol} / 1$ somatostatin $(\mathbf{a}, \mathbf{b} ; n=4)$, somatostatin + somatostatin receptor antagonists $(\mathbf{c}, \mathbf{d})$, and somatostatin receptor antagonist (eh), at $3.5 \mathrm{mmol} / 1(\mathbf{a}, \mathbf{c}, \mathbf{e}-\mathbf{h})$ and $12 \mathrm{mmol} / 1(\mathbf{b}, \mathbf{d}, \mathbf{g}, \mathbf{h})$ glucose $(n=5-8)$. Arginine $(10 \mathrm{mmol} / \mathrm{l})$ was used as positive control (c, d). (f, h) Mean

hormone output averaged over $10 \mathrm{~min}$ before and during infusion in (e) and (g), respectively. Significance was tested by one-way ANOVA (repeated measures). Data are shown as mean \pm SEM. $* * p<0.01$, *** $p<0.001$. Gluc, glucose; SST, somatostatin; SSTr ant, SST receptor antagonist

demonstrated with infusion of somatostatin receptor antagonists. To obtain full blockade of the somatostatin receptor subtypes expressed in the pancreatic islets, we used a cocktail of somatostatin receptor antagonists PRL2915 and PRL3195, which are inhibitors of somatostatin receptor (SSTR)2, SSTR3 and SSTR5 $[26,27]$. This combination successfully blocked any effect of exogenous somatostatin on insulin and glucagon secretion (Fig. $1 \mathrm{c}, \mathrm{d})$ and was used in the subsequent experiments. Glucagon secretion increased $\sim 1.8$-fold $(p<0.01)$ at $3.5 \mathrm{mmol} / 1$ glucose, and $\sim 4$-fold $(p<0.001$; Fig. 1e,f) at $12 \mathrm{mmol} / 1$ glucose, reflecting higher glucose-stimulated somatostatin levels. Somatostatin receptor blockade had no effect on insulin secretion at low glucose, but significantly increased insulin secretion at $12 \mathrm{mmol} / 1$ glucose ( 2-fold, $p<0.01$, Fig. 1g,h). Together, these experiments confirmed the strong tonic inhibitory role of somatostatin on glucagon and insulin secretion as previously demonstrated [12]. Importantly, somatostatin does not seem to have an inhibitory role on insulin secretion at low glucose, but only on glucagon secretion.

\section{Exogenous glucagon stimulates somatostatin secretion through glucagon and GLP-1 receptors}

Initially, glucagon $(0.1,1$ and $10 \mathrm{nmol} / \mathrm{l})$ was added to the arterial perfusate of perfused pancreases at glucose levels of 3.5 and $12 \mathrm{mmol} / 1$ glucose (Fig. 2). However, basal somatostatin

secretion and responses to glucagon were low at $3.5 \mathrm{mmol} / \mathrm{l}$ glucose (reflecting only weak glucose-stimulated somatostatin secretion), and we therefore focused on investigating somatostatin at higher glucose concentrations. At $12 \mathrm{mmol} / \mathrm{l}$ perfusate glucose levels, somatostatin secretion was significantly stimulated by $1-10 \mathrm{nmol} / \mathrm{l}$ glucagon infusions in pancreases of control mice ( 2-fold, $* * p<0.01$; Fig. 2c,d). When blocking the GLP-1 receptor by addition of antagonist Ex9, only $10 \mathrm{nmol} / \mathrm{l}$ glucagon was able to significantly stimulate somatostatin secretion (Fig. 2e,f). In glucagon receptor knockout mice (Fig. 2g,h), glucagon infusions at any dose failed to significantly stimulate secretion of somatostatin, indicating that glucagon-induced somatostatin secretion depends on both glucagon and GLP-1 receptors, consistent with the finding that glucagon interacts with both receptors [14, 28]. Combining glucagon and GLP-1 receptor blockade by addition of Ex9 to $\mathrm{Gcgr}^{-/}$mice, significantly reduced the elevated basal somatostatin secretion of the $\mathrm{Gcgr}^{-/}$ mice ( $p<0.05 ; t$ test), indicating that basal somatostatin secretion depends on both glucagon receptor and GLP-1 receptor signalling (Fig. 2i,j).

\section{Somatostatin secretion is not regulated by insulin in perfused mouse pancreases}

To test the paracrine effect of insulin signalling on somatostatin secretion, we initially infused different concentrations of 



Fig. 2 Exogenous glucagon stimulates somatostatin secretion through glucagon and GLP-1 receptors. Somatostatin secretion from perfused mouse pancreases during infusion of glucagon $(0.1-10 \mathrm{nmol} / \mathrm{l})$ at $3.5 \mathrm{mmol} / 1$ glucose $(\mathbf{a}, \mathbf{b})$ or $12 \mathrm{mmol} / 1$ glucose in control mice $(\mathbf{c}, \mathbf{d})$; control mice + Ex9 $(1 \mu \mathrm{mol} / \mathrm{l}$; added $30 \mathrm{~min}$ before $)(\mathbf{e}, \mathbf{f}) ; \mathrm{Gcgr}^{-1-}$ mice $(\mathbf{g}, \mathbf{h})$; and $\mathrm{Gcgr}^{--}$mice + $\operatorname{Ex9}(\mathbf{i}, \mathbf{j})$. (b, d, f, h, j) Mean somatostatin output averaged over $10 \mathrm{~min}$ before and during infusion of glucagon. Significance was tested by one-way ANOVA (repeated measures) comparing stimulated output vs respective basal output. Data are shown as mean \pm SEM; $n=6-12 ; * p<0.05, * * p<0.01$, ***p $p<0.001$. Gcg, glucagon; SST, somatostatin insulin to perfused mouse pancreases. Exogenous insulin had no acute effect on somatostatin secretion at 3.5 or $12 \mathrm{mmol} / \mathrm{l}$ glucose (Fig. 3a). Addition of the insulin receptor antagonist S961 likewise had no effect on basal secretion, glucose- or arginine-stimulated somatostatin secretion (Fig. 3b,c). To verify that glucagon-stimulated somatostatin secretion does not depend on insulin signalling, we infused glucagon (as above) with continuous addition of S961 (Fig. 3d,e). However, the exogenous glucagon infusions stimulated somatostatin secretion to a similar degree as in control mice (Fig. 2c), supporting the likelihood that insulin is not the main driver behind glucagon-regulated somatostatin secretion. This suggests that the effect of glucagon on somatostatin secretion is not indirectly mediated via insulin (neither glucagonstimulated insulin secretion nor any other acutely stimulated insulin secretion).

\section{Endogenous glucagon signalling affects somatostatin secretion}

In pancreases from control mice (Fig. 4), somatostatin secretion was significantly stimulated by arginine and $12 \mathrm{mmol} / \mathrm{l}$ glucose $(1.4-1.6$ - fold; $p<0.05)$. In mice with DT-induced knockdown of glucagon secretion (Fig. 4c, [14]), the somatostatin response to $12 \mathrm{mmol} / \mathrm{l}$ glucose and arginine infusion was completely lost compared with control mice (Fig. 4a,b). Furthermore, total somatostatin output was reduced by DT treatment (total response $973 \pm 143 \mathrm{fmol} / 75 \mathrm{~min}$ vs $1820 \pm$ 359 in control mice; $p<0.05$ ). Infusion of GLP-1 and a mix of amino acids (Arg, Gln, Glu, Ala) were able to significantly $(p<0.01)$ stimulate somatostatin secretion in DT-Gcg mice, indicating that the delta cells are still functional (Fig. 4d) and capable of responding to strong stimuli. The GLP-1 receptor antagonist Ex9 acutely reduced somatostatin secretion with $50 \%$ in wild-type mice (Fig. 4e) indicating that activation of the GLP-1 receptor is important for somatostatin secretion. This effect was lost in DT-Geg mice where all proglucagon products are knocked down (Fig. 4e) indicating a direct effect mediated by GLP-1 receptor activation. Pancreases from $\mathrm{Gcgr}^{-1-}$ mice with dramatically increased glucagon levels (Fig. 4h, [14]), exhibited an almost twofold increased total somatostatin output compared with control mice (Fig. 4f,g). Addition of the GLP-1 receptor antagonist Ex9 to perfused $\mathrm{Gcgr}^{-1-}$ or control pancreases reduced glucose-stimulated secretion of somatostatin, and administration of Ex-9 to perfused $\mathrm{Gcgr}^{-/-}$pancreases abolished all increments in somatostatin secretion.

\section{Discussion}

Regulation of secretion of the pancreatic hormones and the role of intra-islet communication has been investigated for 

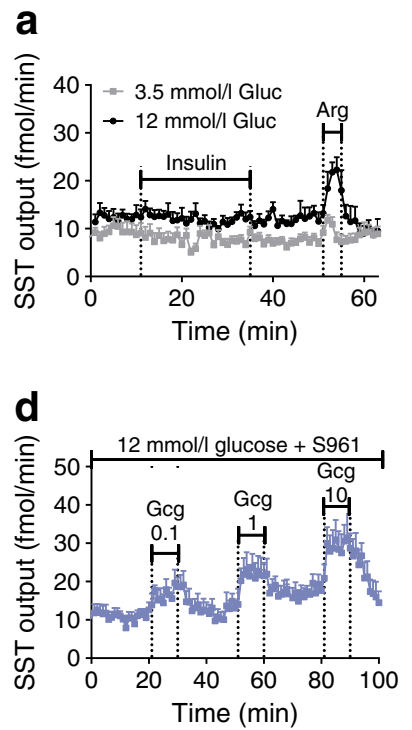

Fig. 3 Somatostatin secretion is not directly regulated by insulin. (a-c) Somatostatin secretion was measured from perfused mouse pancreases of wild-type mice during infusion of insulin at 3.5 and $12 \mathrm{mmol} / 1$ glucose $(n=8-10)(\mathbf{a})$, the insulin receptor antagonist S961 $(1 \mu \mathrm{mol} / \mathrm{l})$ at 3.5 and $12 \mathrm{mmol} / \mathrm{l}$ glucose $(n=5-7)(\mathbf{b})$, and during stimulation with arginine $(10 \mu \mathrm{mol} / \mathrm{l})$ at $12 \mathrm{mmol} / \mathrm{l}$ glucose with or without addition of S961 $(n=$

many years, but several questions remain unanswered. The complex structure of the individual pancreatic islets, the confusing and species-specific arrangement of the microcirculation, and the three predominating hormones, each with a powerful regulating effect on the secretion of each other, complicate the design of experiments and interpretation. It is becoming increasingly clear that, by looking at single cells types separately or isolated islets, deprived of the natural microcirculation, one misses important paracrine effects that each hormone and cell type exert on its surrounding cells, because all substances reach the peripheral cells by uncontrolled diffusion.

In agreement with previous results $[6,12]$, we initially confirmed that a complete blockade of all islet somatostatin receptor subtypes increases the secretion of both glucagon and insulin. The effects on glucagon secretion are profound at both 3.5 and $12 \mathrm{mmol} / 1$ glucose, indicating that endogenous somatostatin is secreted and exerts paracrine effects at both low and high glucose, although somatostatin secretion is dependent on the prevailing glucose levels. Thus, at $12 \mathrm{mmol} / \mathrm{l}$ glucose, the proportionate effect of somatostatin receptor antagonism is more pronounced, but glucagon secretion is still lower compared with secretion at hypoglycaemia. This could indicate that glucose plays a direct role in regulating glucagon secretion, and somatostatin is only partly responsible for glucose-mediated glucagon secretion [29, 30]. Insulin secretion was only affected by somatostatin at $12 \mathrm{mmol} / \mathrm{l}$ glucose, demonstrating that a tonic inhibition by endogenous somatostatin does not contribute to the very low levels of insulin at low glucose levels, whereas a paracrine


11-13) (c). (d) Somatostatin secretion during infusion of exogenous glucagon $(0.1-10 \mathrm{nmol} / \mathrm{l})$ and simultaneous infusion of S961 $(n=8)$. (e) Mean somatostatin output averaged over $10 \mathrm{~min}$ before and during addition of glucagon in (d). Significance was tested by one-way ANOVA with post hoc Tukey adjustment. Data are shown as mean \pm SEM. $* p<0.05$. Gcg, glucagon; Gluc, glucose; SST, somatostatin

inhibitory effect by local somatostatin plays a significant role in the regulation of insulin secretion at higher glucose levels. Having confirmed the profound influence of somatostatin on glucagon secretion, we wished to investigate whether glucagon also plays a role in somatostatin secretion.

\section{Glucagon can directly stimulate somatostatin secretion, independently of insulin}

Studies have demonstrated that glucagon plays a role in stimulating insulin secretion by a direct effect on glucagon and GLP-1 receptors expressed on the beta cells $[12,14,17]$. A similar effect of glucagon on somatostatin secretion has been suspected based on reduced somatostatin secretion in response to glucagon antibodies [2], in agreement with effects of exogenous glucagon effects in isolated islets [20,31]. We here demonstrate that exogenous glucagon stimulates somatostatin secretion in the perfused mouse pancreas with preserved microcirculation. The effect is greater at high glucose levels, consistent with a stimulating effect of glucose on somatostatin secretion, similar to what is found for beta cells. We and others have previously demonstrated that both glucagon and GLP-1 receptors are expressed in delta cells, although at lower levels than in beta cells $[12,32]$. In the present experiments, antagonising either the glucagon or GLP-1 receptor reduced or completely abolished the effect of glucagon on somatostatin secretion, suggesting that both receptors are involved in glucagon's regulation of the delta cell. The significant reduction in somatostatin secretion with addition of a GLP-1 receptor antagonist clearly demonstrated that activation of the GLP- 



Fig. 4 Endogenous glucagon signalling affects somatostatin secretion from perfused mouse pancreases. (a-b) Somatostatin and (c) glucagon secretion from the pancreas of DT-Gcg and control mice perfused at 3.5 and $12 \mathrm{mmol} / \mathrm{l}$ glucose with infusion of arginine $(n=7-8$; key in a also applies to c). (d) Somatostatin secretion from DT-Geg mice in response to $10 \mathrm{nmol} / \mathrm{l} \mathrm{GLP}-1$ and amino acids (Arg, Glu, Gln, Ala) $(n=6)$. (e) Ex9 $(1 \mu \mathrm{mol} / \mathrm{l})$ infused at $12 \mathrm{mmol} / \mathrm{l}$ glucose in wild-type and DT-Gcg mice $(n=5-6)$. (f-h) secretion from $\mathrm{Gcgr}^{-/}$and $\mathrm{Gcgr}^{+/+}$mouse pancreases with or without addition of $\operatorname{Ex} 9\left(n=7-11\right.$; in $\mathbf{f}, \mathbf{g ~} \mathrm{Gcgr}^{+/+}$black/circles;

1 receptor is important for regulating somatostatin secretion. Since glucagon can activate both glucagon and GLP-1 receptors $[14,28]$, this would indicate a stimulating paracrine role of endogenous glucagon/GLP-1 on somatostatin secretion. Considering that the level of islet GLP-1 secretion is minimal compared with glucagon [14], it is likely that this effect reflects the actions of glucagon. Furthermore, the effect of GLP-1 receptor antagonism was lost in DT-Gcg mice, indicating that the effect of Ex9 is directly mediated by proglucagon products. Other studies have suggested that insulin can stimulate somatostatin secretion [18, 19], which could mean that the effect of glucagon on somatostatin secretion could be indirect, mediated through glucagon-induced insulin secretion. However, addition of the insulin receptor antagonist S961 had no influence on the effect of glucagon on somatostatin secretion. Furthermore, addition of up to $1 \mu \mathrm{mol} / 1$
$\mathrm{Gcgr}^{-1-}$, purple/squares; $\mathrm{Gcgr}^{+/+}+\mathrm{Ex} 9$, red/inverted triangles; $\mathrm{Gcgr}^{-1-}+$ Ex9, light blue/upright triangles). (b, g) Mean somatostatin output averaged over 5 min before and during addition of glucose and arginine. Significance was tested by one-way ANOVA with post hoc Tukey adjustment. Data are shown as mean \pm SEM. $* p<0.05$, $* * p<0.01$, $* * * p<0.001$ comparing wild-type littermates vs $\mathrm{Gcgr}^{-1-} ;{ }^{\dagger} p<0.05$, ${ }^{\dagger \dagger} p<0.001$ comparing control vs DT-Geg or $\mathrm{Gcgr}^{-{ }^{--}} \pm$Ex9. Data on glucagon secretion $(\mathbf{c}, \mathbf{h})$ have been previously published elsewhere [14]. AA, amino acids; SST, somatostatin

insulin to the perfusate did not have any effect on somatostatin secretion (Fig. 3) in line with previous studies [20, 33], and infusion of insulin receptor antagonist S961 neither affected basal nor glucose- or arginine-stimulated somatostatin secretion. This suggests that insulin does not play a direct role in paracrine regulation of somatostatin secretion in mice.

\section{Somatostatin secretion requires normal intra-islet glucagon signalling}

To investigate the intra-islet paracrine effects of endogenous glucagon on somatostatin secretion, we used transgenic mouse models to disrupt glucagon signalling. We have previously utilised DT-induced destruction of proglucagon cells in transgenic mice expressing the human DT receptor under control of the proglucagon promoter to acutely knock down 
the alpha cells and thereby glucagon secretion. These mice also exhibited significantly reduced insulin secretion, indicating that normal glucagon secretion is necessary to maintain appropriate insulin secretion $[14,21]$. We here report that somatostatin secretion in these mice was likewise reduced compared with control mice. They were still able to secrete somatostatin in response to GLP-1 showing that the delta cells are still functional although with a lower level of basal somatostatin secretion. The lack of an arginine-stimulated response may therefore reflect a need for a rise in glucagon (which is lost in DT-Gcg mice) for arginine-stimulated somatostatin secretion, whereas GLP-1 may directly stimulate somatostatin through GLP-1 receptors on the delta cells. However, it is also possible that a basic tone of glucagon stimulation is required to maintain normal somatostatin secretion, without which responses to other stimuli are lost.

Global $\mathrm{Gggr}^{-1-}$ mice have alpha cell hyperplasia and 20-fold increased glucagon secretion, and to a lesser extent delta cell hyperplasia [14, 22]. In these islets, we also identified increased secretion of small amounts of active GLP-1 from the islets, presumably reflecting a general increase in proglucagon formation compared with control mice [14]. In the present experiments, somatostatin secretion from $\mathrm{Gcgr}^{-/-}$mice was significantly increased compared with control mice. This could be explained by an increased GLP-1 receptor activation (from increased secretion of glucagon as well as GLP-1). Consistent with this notion, simultaneous blockade of glucagon and GLP-1 receptors terminated somatostatin secretion, similar to what has previously been shown for insulin secretion [14, 34]. In general, this would suggest that glucagon does exhibit a stimulating effect on somatostatin secretion and that alpha cells regulate the function of both delta- and beta cells. The constitutive knockout of glucagon receptors in the $\mathrm{Gcgr}^{-1-}$ model has limitations due to compensatory mechanisms taking place, and the hypersecretion of proglucagon products complicates the overall picture. However, combined with the other models, it demonstrates an important role for glucagon acting directly within the pancreas on the secretion of islet hormones. Experimental inhibition of glucagon actions requires a simultaneous inhibition of both glucagon and GLP-1 receptors. Likewise, the use of GLP-1 receptor antagonists not only blocks GLP-1 but also any potential action of glucagon on GLP-1 receptors.

The role of somatostatin is still largely unresolved but its strong ability to inhibit hormone secretion is indisputable. Studies to investigate intra-islet communication are complicated by the fact that we cannot directly see what happens in each islet. Glucagon seems to stimulate secretion insulin [14, 16, 34] and somatostatin $[2,31,35]$, while somatostatin plays a strong inhibitory role on insulin and glucagon secretion, suggesting that the islets are locked in a push-pull feedback regulation. Considering the observed dysregulated insulin and glucagon secretion in type 2 diabetes [36, 37], it is possible that somatostatin could play a role in the development of type 2 diabetes
[32-34]. Moreover, it has been suggested that the use of somatostatin receptor antagonists could potentially be used to correct the impaired glucagon secretion observed in people with type 2 diabetes in response to hypoglycaemia, where somatostatin does not seem to affect insulin secretion, as demonstrated in a rat model of diabetes [38-40]. The potential use of somatostatin as a therapeutic tool makes it important to know more about the secretion and actions of somatostatin in the pancreas both in normal physiology and under diabetic conditions. However, it is notoriously difficult to measure somatostatin in plasma due to an almost immediate break down. In addition, any surviving somatostatin in peripheral plasma might be derived from all regions of the gastrointestinal tract or the pituitary, not specifically from the pancreas. Furthermore, plasma levels of somatostatin-14 or -28 are very low, challenging the sensitivity of the applied assays. Therefore, most studies have been performed on isolated cells/islets/pancreas. This would be consistent with notions that somatostatin does not function as a circulating hormone, but mainly acts as a paracrine regulator acting locally on neighbouring cells in pancreatic islets and the intestine. The potential importance of somatostatin as a paracrine regulator has been demonstrated in several studies, where stimulators of somatostatin secretion (e.g. GLP-1, ghrelin) reduce glucagon and/or insulin secretion in a somatostatindependent manner [11, 12, 32]. Furthermore, the strong inhibitory effect of somatostatin on glucagon secretion has been suggested to play a role in glucose-reduced glucagon secretion $[13,29]$. Thus, in conditions with high glucose, somatostatin secretion is increased and glucagon secretion reduced. The current studies indicate that, not only is somatostatin likely to profoundly regulate secretion of the alpha and beta cells, but somatostatin secretion is itself regulated by glucagon secretion. This might be important for both basal and amino acidstimulated somatostatin secretion, whereas insulin did not seem to influence somatostatin secretion. Our results reinforce the concept that the pancreatic islets function as a complex integrated endocrine organ with important paracrine feedback cycles, tying the secretion by the many cell types together.

Acknowledgements Some of these data were presented as an abstract at the 55th EASD Annual Meeting in 2019.

Data availability The datasets generated and analysed during the current study are available from the corresponding authors on reasonable request.

Funding This study was supported by grants from the Danish Council for Independent Research (6110-00660), the Lundbeck Foundation (20119560, 2016-2394), the European Foundation for the Study of Diabetes (EFSD-Lilly Young Investigator Research Award 2019), and the Novo Nordisk Foundation.

Contribution statement Both authors contributed substantially to (1) conception and design, acquisition of data, analysis and interpretation of data as well as (2) drafting and critical revision for important intellectual content and (3) both approved of the version to be published. BS and $\mathrm{JJH}$ are the guarantors of this work. 
Authors' relationships and activities JJH has served as a consultant or advisor to Novo Nordisk, Merck Sharp \& Dohme, and Roche and received fees for lectures from Novo Nordisk, Merck Sharp \& Dohme, and GlaxoSmithKline. The authors declare that there are no other relationships or activities that might bias, or be perceived to bias, their work.

\section{References}

1. Cabrera O, Berman DM, Kenyon NS, Ricordi C, Berggren PO, Caicedo A (2006) The unique cytoarchitecture of human pancreatic islets has implications for islet cell function. Proc Natl Acad Sci U S A 103(7):2334-2339. https://doi.org/10.1073/pnas.0510790103

2. Stagner JI, Samols E, Marks V (1989) The anterograde and retrograde infusion of glucagon antibodies suggests that $\mathrm{A}$ cells are vascularly perfused before D cells within the rat islet. Diabetologia 32(3):203-206. https://doi.org/10.1007/BF00265095

3. Stagner JI, Samols E (1992) The vascular order of islet cellular perfusion in the human pancreas. Diabetes 41(1):93-97. https:// doi.org/10.2337/diab.41.1.93

4. Schusdziarra V, Dobbs RE, Harris V, Unger RH (1977) Immunoreactive somatostatin levels in plasma of normal and alloxan diabetic dogs. FEBS Lett 81(1):69-72. https://doi.org/10.1016/ 0014-5793(77)80930-7

5. Holst JJ, Sottimano C, Olesen M, Lindkaer S, Nielsen OV (1981) Nervous control of gastro-pancreatic somatostatin secretion in pigs. Peptides 2(Suppl 2):215-221

6. Maruyama H, Hisatomi A, Orci L, Grodsky GM, Unger RH (1984) Insulin within islets is a physiologic glucagon release inhibitor. J Clin Invest 74(6):2296-2299. https://doi.org/10.1172/JCI111658

7. Samols E, Stagner JI (1988) Intra-islet regulation. Am J Med 85(5a):31-35

8. Kumar U, Sasi R, Suresh S et al (1999) Subtype-selective expression of the five somatostatin receptors (hSSTR1-5) in human pancreatic islet cells: a quantitative double-label immunohistochemical analysis. Diabetes 48(1):77-85. https://doi.org/10.2337/ diabetes.48.1.77

9. Portela-Gomes GM, Stridsberg M, Grimelius L, Oberg K, Janson ET (2000) Expression of the five different somatostatin receptor subtypes in endocrine cells of the pancreas. Appl Immunohistochem Mol Morphol 8(2):126-132. https://doi.org/10. 1097/00129039-200006000-00007

10. Johnson DG, Ensinck JW, Koerker D, Palmer J, Goodner CJ (1975) Inhibition of glucagon and insulin secretion by somatostatin in the rat pancreas perfused in situ. Endocrinology 96(2):370-374. https:// doi.org/10.1210/endo-96-2-370

11. de Heer J, Rasmussen C, Coy DH, Holst JJ (2008) Glucagon-like peptide-1, but not glucose-dependent insulinotropic peptide, inhibits glucagon secretion via somatostatin (receptor subtype 2) in the perfused rat pancreas. Diabetologia 51(12):2263-2270. https://doi.org/10.1007/s00125-008-1149-y

12. Adriaenssens AE, Svendsen B, Lam BY et al (2016) Transcriptomic profiling of pancreatic alpha, beta and delta cell populations identifies delta cells as a principal target for ghrelin in mouse islets. Diabetologia 59(10):2156-2165. https://doi.org/ 10.1007/s00125-016-4033-1

13. Hauge-Evans AC, King AJ, Carmignac D et al (2009) Somatostatin secreted by islet delta-cells fulfills multiple roles as a paracrine regulator of islet function. Diabetes 58(2):403-411. https://doi. org $/ 10.2337 / \mathrm{db} 08-0792$

14. Svendsen B, Larsen O, Gabe MBN et al (2018) Insulin secretion depends on intra-islet glucagon signaling. Cell Rep 25(5):11271134.e1122. https://doi.org/10.1016/j.celrep.2018.10.018
15. Samols E, Marri G, Marks V (1965) Promotion of insulin secretion by glucagon. Lancet 2(7409):415-416. https://doi.org/10.1016/ s0140-6736(65)90761-0

16. Huypens P, Ling Z, Pipeleers D, Schuit F (2000) Glucagon receptors on human islet cells contribute to glucose competence of insulin release. Diabetologia 43(8):1012-1019. https://doi.org/10.1007/ s001250051484

17. Moens K, Flamez D, Van SC, Ling Z, Pipeleers D, Schuit F (1998) Dual glucagon recognition by pancreatic beta-cells via glucagon and glucagon-like peptide 1 receptors. Diabetes 47(1):66-72. https://doi.org/10.2337/diab.47.1.66

18. Vergari E, Knudsen JG, Ramracheya R et al (2019) Insulin inhibits glucagon release by SGLT2-induced stimulation of somatostatin secretion. Nat Commun 10(1):139. https://doi.org/10.1038/ s41467-018-08193-8

19. Honey RN, Fallon MB, Weir GC (1980) Effects of exogenous insulin, glucagon, and somatostatin on islet hormone secretion in the perfused chicken pancreas. Metab Clin Exp 29(12):1242-1246. https://doi.org/10.1016/0026-0495(80)90152-3

20. Hauge-Evans AC, Anderson RL, Persaud SJ, Jones PM (2012) Delta cell secretory responses to insulin secretagogues are not mediated indirectly by insulin. Diabetologia 55(7):1995-2004. https:// doi.org/10.1007/s00125-012-2546-9

21. Pedersen J, Ugleholdt RK, Jorgensen SM et al (2013) Glucose metabolism is altered after loss of L cells and alpha-cells but not influenced by loss of K cells. Am J Physiol Endocrinol Metab 304(1):E60-E73. https://doi.org/10.1152/ajpendo.00547.2011

22. Gelling RW, Du XQ, Dichmann DS et al (2003) Lower blood glucose, hyperglucagonemia, and pancreatic alpha cell hyperplasia in glucagon receptor knockout mice. Proc Natl Acad Sci U S A 100(3):1438-1443

23. Schaffer L, Brand CL, Hansen BF et al (2008) A novel high-affinity peptide antagonist to the insulin receptor. Biochem Biophys Res Commun 376(2):380-383. https://doi.org/10.1016/j.bbrc.2008.08. 151

24. Orskov C, Jeppesen J, Madsbad S, Holst JJ (1991) Proglucagon products in plasma of noninsulin-dependent diabetics and nondiabetic controls in the fasting state and after oral glucose and intravenous arginine. J Clin Invest 87(2):415-423. https://doi.org/10.1172/ jci1 15012

25. Brand CL, Jorgensen PN, Knigge U et al (1995) Role of glucagon in maintenance of euglycemia in fed and fasted rats. Am J Physiol Endocrinol Metab 269(3):E469-E477. https://doi.org/10.1152/ ajpendo.1995.269.3.E469

26. Hocart SJ, Jain R, Murphy WA, Taylor JE, Coy DH (1999) Highly potent cyclic disulfide antagonists of somatostatin. J Med Chem 42(11):1863-1871. https://doi.org/10.1021/jm9806289

27. Rajeswaran WG, Hocart SJ, Murphy WA, Taylor JE, Coy DH (2001) Highly potent and subtype selective ligands derived by Nmethyl scan of a somatostatin antagonist. J Med Chem 44(8):13051311. https://doi.org/10.1021/jm0005048

28. Jorgensen R, Kubale V, Vrecl M, Schwartz TW, Elling CE (2007) Oxyntomodulin differentially affects glucagon-like peptide-1 receptor beta-arrestin recruitment and signaling through Galpha(s). J Pharmacol Exp Ther 322(1):148-154. https://doi.org/ 10.1124/jpet.107.120006

29. Lai BK, Chae H, Gomez-Ruiz A et al (2018) Somatostatin is only partly required for the glucagonostatic effect of glucose but is necessary for the glucagonostatic effect of $\mathrm{K}_{\mathrm{ATP}}$ channel blockers. Diabetes 67(11):2239-2253. https://doi.org/10.2337/db17-0880

30. Yu Q, Shuai H, Ahooghalandari P, Gylfe E, Tengholm A (2019) Glucose controls glucagon secretion by directly modulating cAMP in alpha cells. Diabetologia 62(7):1212-1224. https://doi.org/10. 1007/s00125-019-4857-6

31. Dolais-Kitabgi J, Kitabgi P, Freychet P (1981) Glucose and glucagon do stimulate somatostatin release from isolated pancreatic 
islets. Diabetologia 21(3):238. https://doi.org/10.1007/ BF00252662

32. DiGruccio MR, Mawla AM, Donaldson CJ et al (2016) Comprehensive alpha, beta and delta cell transcriptomes reveal that ghrelin selectively activates delta cells and promotes somatostatin release from pancreatic islets. Mol Metab 5(7):449-458. https:// doi.org/10.1016/j.molmet.2016.04.007

33. Murakami K, Taniguchi H, Tamagawa M, Ejiri K, Baba S (1982) Modulation of somatostatin release by endogenous glucagon and insulin: physiological relationship between A, B and D cells in rat pancreatic islets. Endocrinol Jpn 29(5):503-508. https://doi.org/10. 1507/endocrj1954.29.503

34. Capozzi ME, Svendsen B, Encisco SE et al (2019) $\beta$ Cell tone is defined by proglucagon peptides through cAMP signaling. JCI Insight 4(5). https://doi.org/10.1172/jci.insight.126742

35. Patton GS, Dobbs R, Orci L, Vale W, Unger RH (1976) Stimulation of pancreatic immunoreactive somatostatin (IRS) release by glucagon [proceedings]. Metab Clin Exp 25(11 Suppl 1):1499. https:// doi.org/10.1016/s0026-0495(76)80177-1

36. Unger RH, Orci L (2010) Paracrinology of islets and the paracrinopathy of diabetes. Proc Natl Acad Sci 107(37):1600916012. https://doi.org/10.1073/pnas. 1006639107
37. D'Alessio D (2011) The role of dysregulated glucagon secretion in type 2 diabetes. Diabetes Obes Metab 13(s1):126-132. https://doi. org/10.1111/j.1463-1326.2011.01449.x

38. Yue JT, Burdett E, Coy DH, Giacca A, Efendic S, Vranic M (2012) Somatostatin receptor type 2 antagonism improves glucagon and corticosterone counterregulatory responses to hypoglycemia in streptozotocin-induced diabetic rats. Diabetes 61(1):197-207. https://doi.org/10.2337/db11-0690

39. Yue JT, Riddell MC, Burdett E, Coy DH, Efendic S, Vranic M (2013) Amelioration of hypoglycemia via somatostatin receptor type 2 antagonism in recurrently hypoglycemic diabetic rats. Diabetes 62(7):2215-2222. https://doi.org/10.2337/db12-1523

40. Karimian N, Qin T, Liang T et al (2013) Somatostatin receptor type 2 antagonism improves glucagon counterregulation in biobreeding diabetic rats. Diabetes 62(8):2968-2977. https://doi.org/10.2337/ db13-0164

Publisher's note Springer Nature remains neutral with regard to jurisdictional claims in published maps and institutional affiliations. 